\title{
QUALITY OF LIFE AND QUALITY OF LIVING IN RURAL COMMUNES IN POLAND
}

Agnieszka Michalska-Żyła ${ }^{1}$, Małgorzata Marks-Krzyszkowska²

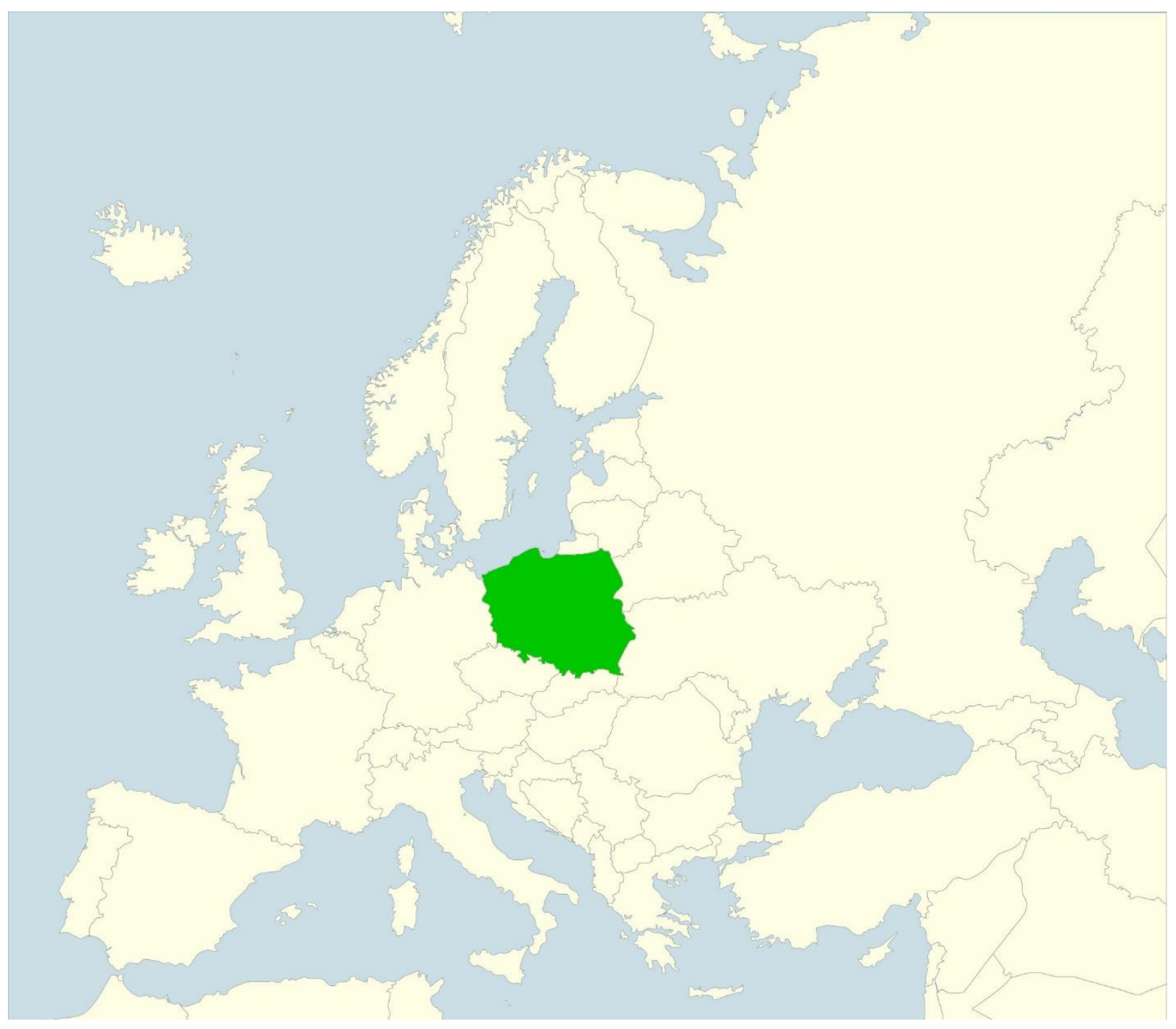

\footnotetext{
${ }^{1}$ Ph.D Agnieszka Michalska-Żyła, University of Łódź, Faculty of Sociology and Economics, Department of Rural and Urban Sociology, Rewolucji 1905r. 41/43, 90-214 Łódź, Poland, e-mail: amichalskazyla@wp.pl

2 Ph.D Małgorzata Marks-Krzyszkowska, University of Łódź, Faculty of Sociology and Economics, Institute of Spatial Economics, Department of Local Government Economics, Rewolucji 1905r. 41/43, 90-214 Łódź, Poland, e-mail: malmarks@o2.pl
} 
Abstract: Quality of life is an issue taken into account increasingly more often as one of the main elements of the evaluation and in comparisons between countries, regions and communes (local governments). The aim of this article is to show the relationship between quality of life and quality of living in rural communities at varying levels of socio-economic development. The analysis of both aspects yields the opportunity to observe the relationship between objective resources of the local community as well as the level of their socio-economic condition and level of satisfaction of the inhabitants, the latter of which results from, inter alia, their ability to meet specific needs within the local environment. The presented analysis leads to several main conclusions. The first is that the rural residents who participated in the study were characterized by a relatively high satisfaction with their own lives. The main source of their life satisfaction was the family sphere. The greatest source of dissatisfaction was their financial situation. The second conclusion comes from the analysis of their subjective assessment of their quality of living in terms of the local commune. The examined residents overall positively assessed the conditions of living in their community. They were content, first and foremost, with the natural environment and security. The lowest level of satisfaction with living in the commune was associated with such aspects as technical infrastructure, transport links, activities of NGOs and political parties, and the lack of possibilities to exert influence on what is happening in the commune. However, it is difficult to specify general correlations that would clarify the relationship between quality of life and quality of living in rural communities. The regression analysis confirmed the weak link between these phenomena. The final conclusion confirms the thesis of the high heterogeneity and diversity of rural communes in Poland, even within a socially, culturally and economically coherent area of a voivodeship (province).

Keywords: quality of life, quality of living, rural areas, rural communes, Poland

\section{Introduction}

Rural areas in Poland constitute over $90 \%$ of its surface area and are inhabited by approximately 14 million people, which justifies exploring the quality of life of this population, both for cognitive and practical reasons. The literature, however, provides few empirical analyses devoted to the quality of life in rural areas in Poland. Those that are available relate to international comparisons (Kovach, 1997; Spellerberg et al., 2007), regional/sub-regional perspectives (Kobylińska, 2010; Adamska, 2006; Murawska, 2012), and comparing urban and rural or urban areas only (Heffner and Klemens, 2012; Michalska-Żyła, 2014; Raphael et al., 1998; Rokicka, 2014). This does not mean, however, that individual elements of the contemporary concept of quality of life have not been examined. The undertaken research has attempted mainly to focus on the characteristics of living conditions of rural households in relation to the technical and social infrastructure of their rural space (Pięcek, 2001; Szymczak, 2005). They have pointed to the significant disparities between the countryside and the city. Nowadays, the distance in the standard of living of the inhabitants of urban and rural areas is becoming increasingly blurred. However, despite many favourable quantitative and qualitative changes, rural areas in Poland are internally differentiated (Bański and Pantyley, 2013; Rosner, 2010; Heffner and Rosner, 2005), which is a derivative of the historical, economic, spatial and socio-cultural factors affecting rural areas (Rosner, 2010; Gorlach and Starosta, 2016). The findings concerning essential disproportions on an east-west divide, which indicate the underdevelopment of areas situated in the vicinity of the eastern Polish border (Stanny, et al., 2016; Hryniewicz, 2015), are well known. Equally significant are the differences in the level of development and living conditions of the rural populations in the very same voivodeship, and often even in the same poviat (the form of administrative local self-government, hereinafter referred to as 'commune' or sometimes 'village'). One may encounter areas that are just slightly different from urban areas, as well as those with a traditional, scattered developmental structure, dominated by agricultural activity. Recognition of 
the conditions of such a diverse rural environment enables an individual approach to solving problems in a way appropriate and beneficial for the stakeholders.

The aim of this article is to show the relationship between subjective quality of life and subjective quality of living in rural communities of varying levels of socio-economic development.

\section{Rural areas - background considerations}

Starting from the post-war period, rural areas in Poland have been subject to constant transformations. The current socio-economic situation of the villages and their inhabitants is a result of historical and political conditions, the effects of the 1990s regime reforms (the transformation period), and Poland's accession to the EU structures in 2004.

Rural areas, since the beginning of the transformation period, have been attributed the trait of "underdevelopment", which was the result of poor incentives to invest due to lack of infrastructure, lack of own capital, and low qualifications of the population. It was even written that rural areas were affected by a "civilizational collapse" (Kłodziński, 1999). Living in the countryside was then perceived as a sort of social degradation, while the opportunity to break away and live in the city was associated with social advancement (Zawisza, 1997). From the perspective of the development of the whole society, it was therefore necessary to take measures to eliminate the negative overall state and to improve the conditions and quality of life in rural communities.

The transformation towards a democratic system, and the development of self-government and free-market management, were launched in Poland at the turn of 1980s and 1990s (Cf. Swianiewicz, 2013; Yoder, 2003). However, the chaotic agricultural policy (or the lack thereof at an early stage) and the engrained habits of subordination to central management became, and remain, major barriers to free-market activities in the countryside and agriculture (Gorlach and Mooney, 1998). Moreover, in the initial period of the transformation the state almost entirely withdrew from its subsidization of agriculture. The farmers' incomes shrank as production prices rose. These negative effects were intensified by the resulting low agricultural productivity. The crisis in agriculture gained momentum, which was especially felt by rural residents. The difficulties in repaying the loans taken out by individual farmers increased, and State Agricultural Farms (the so-called PGRs) were unable to bear the tax burden by themselves. A state of disorganization and crisis reigned in the countryside and in agriculture. The responses to this were (and still are) corrective actions taken by successive governments and a more thoughtful policy of strategic management of rural areas and the agricultural sector. These actions have focused on the development of new (non-agricultural) functions for rural areas. Following the accession of Poland to the European Union, the stream of funding for various socio-economic initiatives increased considerably, and the economic situation of the rural population began to improve (Furmankiewicz et al., 2016; Podedworna, 2010; Nurzyńska, 2016).

The results of research and analysis of the development of rural areas in Poland manifest these changes. First of all, their reported development takes place in the expected multifunctional direction. Agriculture has been supplemented by other functions, both service-related and residential. The share of agriculture in GDP is decreasing, as well as the area devoted to this activity and the share of people employed in agriculture (Halamska, 2011, 2016). The financial and occupational condition of the inhabitants, no longer related solely to agriculture but also to other sectors of the economy, has improved, although poverty still remains a problem in rural areas (Zegar and Chmielewska, 2016). In terms of demographics, villages are becoming similar to cities, as evidenced by fertility, birth and infant mortality rates (Frenkel, 2016). The level of education index has increased, reflecting the increased educational aspirations of young rural residents. The balance of migration to the countryside, while negative, is nevertheless increasing. The current demographic situation in rural areas is in some ways more advantageous than in urban areas. Despite this, the demographic projections for Poland indicate the existence of two potential problems: the aging of the population and the deepening of the peripheral position of some regions (i.e., a significant outflow of their populations). The population growth in rural areas is expected to take place mainly in the suburban areas of major Polish cities. There are also increases in the level of applications by local self-governments for EU funds, in the level of residents' satisfaction with the authorities, and in the level of their satisfaction with their place of 
residence. Problems remain, however, with regard to the availability and quality of social and communication infrastructure and the low level of interest of the rural population in public matters, which significantly limits the developmental potential of rural areas.

The socio-economic situation of rural areas is gradually improving, although in some places it is still poor compared with other regions of the European Union (Nurzyńska, 2016; Wilkin, 2016). Despite the positive changes when compared to the beginning of the transformation period, there is still a visible substantial interregional variation in the level of development of different communes (Rosner, 2010), mostly on the centre-periphery divide. This leads to the conclusion that in spite of the implemented policy of equalizing the differences in the levels of development, "pro-cohesive tendencies in the territorial dimension are lost to those that promote further differentiation of the level of development" (Rosner, 2010:23). The reasons mentioned include the following factors: poorly planned and inappropriately spent funds; inconsistent and illprepared strategic plans; and lack of cooperation with the external and local environments.

Improving the quality of life in rural areas is a goal that is inscribed in the main dimensions of socio-economic development. It is primarily implemented by strengthening their economic potential, restructuring and modernization, as well as improving the quality of the environment, the landscape, the social and technical infrastructure (Murawska, 2012:170).

\section{Quality of life - theoretical grounds}

Quality of life is an issue increasingly taken into account as one of the main elements in the evaluation of and comparisons between countries, regions and communes. It is also listed as a primary objective in creating a concept of local or regional development (Borys, 2001; Borys and Rogala, 2008g), since the pursuit of personal and social well-being and satisfying peoples' needs is the basis for an improved quality of life of both present and future generations, and is the essence of the concept of sustainable development (Kusterka-Jefmańska, 2010).

The literature provides many models used to measure quality of life. Some of them are based on objective aspects, others on subjective aspects. The main difference is that the subjective indicators measure the degree to which the residents' way of thinking or impressions 'touch upon a certain aspect of life', while objective indicators are grounded in criteria that exist independently of the residents' subjective consciousness and can be obtained without directly examining the persons concerned. In attempts to try to take advantage of the positive aspects of both approaches, mixed models are also proposed (Campanera and Higgins, 2011; Costanza et al., 2008). Research on the objective quality of life is currently associated with the improvement of tools for measuring economic well-being, extended by some social and environmental issues.

Objective quality of life encompasses the analysis of the living conditions of individuals and communities in relation to the basic dimensions of both the material conditions and the existential and environmental security of the individuals' lives. The categories most commonly taken into account include: material living conditions, health, education, economic activity, relationships and social relations, functioning of the state, quality of infrastructure, and the environment (Stiglitz et al., 2009: 43-44). The objective approach to quality of life is thus a feature of the social environment which is assessed independent of the ways in which it is perceived and valued. Measuring quality of life in its objective aspect is carried out by referring to the statistical data collected by various institutions, which shows the conditions and standard of living of the inhabitants of regions, cities or villages.

However, focusing solely on the objective dimension of quality of life reduces, to a large extent, the possibility of capturing the full picture of the situation of rural areas. The solution to this problem is to use a model that takes into account both the objective and subjective dimensions of the phenomenon. A comprehensive analysis of quality of life should therefore include both an analysis of the level of living conditions on the basis of objective data, as well as the sense of well-being reported by the members of rural communities themselves.

Measuring the subjective quality of life is as important as measuring its objective aspect. This way of thinking is related to describing the goal of socio-economic development in terms of satisfaction with the changes made. Not surprisingly, the most relevant measures of satisfaction are 
the evaluations made directly by the interested parties themselves (Central Statistical Office (CSO), 2013: 7-8). In addition, some aspects of quality of life are available for the analysis only in the form of subjective assessments made by the respondents, for instance, the degree of satisfying one's higher needs. Knowledge concerning the social perception of living conditions and the degree of satisfaction and the emotional states of the society is also of great importance in planning specific actions in the fields of social and economic policy.

Analysis of the subjective dimension of quality of life is related to measurement of the level of satisfaction of the individual with his or her life, which results from the perception of one's own life within a certain system of values and functioning under certain social, economic and political conditions (Borys and Rogala, 2008). In this context, the level of quality of human life is attested to by the mental states accompanying a person in the process of satisfying his or her needs, resulting from the cognitive evaluation of relations between oneself and the environment, the evaluation of one's own achievements and failures, as well as one's subjective assessment of the chances of realizing his or her aspirations, desires, and life goals (Diener and Suh, 1997; Stiglitz et al., 2009). The subjective dimension of quality of life is, thus, a strongly individualized category that largely depends on the complexity of the needs, attitudes, and aspirations of individuals.

Measurements of the subjective quality of life refer to the assessment of life as a whole and of its particular spheres (Czapiński, 2012). According to Campbell (1976), subjective quality of life depends on the degree to which one meets his or her needs in specific areas of an individual's life, such as marriage, family life, neighbourly and friendly relations, health, professional work, place of residence, leisure, housing conditions, educational background, and overall standard of life.

The quality of life of a resident of a particular community should include the quality of the living environment of his/her place of residence. This is referred to as the 'quality of living'. These are several reasons for its particular importance (Raphael et al., 1998). Firstly, the living environment provides the basis for meeting the needs of the inhabitants with respect to the following aspects: food, shelter, security, health, social support, social interaction, etc. Secondly, it delineates a field of action that allows one to exploit his or her individual potential, while counteracting marginalization, social exclusion and helplessness. And thirdly, it creates opportunities for control and choice (or the lack thereof). The quality of living of a territorial community is therefore manifested by the benefits of and satisfaction with an effective institutional system. Evaluation of the quality of living in the local system also includes, alongside the personal level (individual quality of life) evaluation of the components of the living environment (infrastructure and its accessibility) in terms of its role in shaping the sense of satisfaction among the population (Raphael et. al., 1998).

A high quality of living in the local environment is also an important asset, which for the commune itself, as it can be used to increase its competitiveness in terms of the competition for new residents or investors. It is a kind of incentive for one to tie up his or her fate with the local system.

The pursuit of improvement/enhancement of competitive position is focused on bettering the conditions and quality of living by shaping a favourable socio-cultural as well as spatial environment. Given the intensive competition vis-à-vis migration into rural areas, the commune authorities should strive to create the best environment not only for new users, but also for the satisfaction of those already present. The described trend leads to a situation in which the role of traditional, measurable factors in assessing the attractiveness of individual cities or regions is increasingly taken over by characterizations of a given place associated with cultural and social aspects, as well as the quality of living in the area (Fredriksson, 1998). The economic dimension of competitiveness is therefore largely linked to the social dimension.

The analysis of the objective and subjective aspects of both quality of life and quality of living makes it possible to grasp the relationship between the objective resources of the local community and the level of their socio-economic condition and the degree of satisfaction of the inhabitants resulting from, inter alia, their ability to meet specific needs within the local environment. Examining the degree of coherence between the objective and subjective quality of life and quality of living is also interesting considering the fact that, according to the research, improvement of 
existential conditions does not directly translate into an increase in the level of satisfaction of the inhabitants of territorial communities. A study conducted by Cambell (1976) showed that improving the material living conditions does not always go hand in hand with a change in people's subjective judgment and better evaluation scores. According to Czapiński (2002), no convincing empirical evidence was found to support the thesis of a direct link between economic growth in developed countries and the sense of well-being of their inhabitants. This lack of a correlation may be a consequence of the relatively weaker economic growth of countries with a high level of development. In other words, in developed countries the dynamics of growth is usually weaker because of its high level of development already attained (Starosta and Michalska-Żyła, 2016). The situation in developing countries is quite different. Developmental processes aimed at eliminating the civilizational delays and deprivations in many spheres and areas of the local environment, and reducing the distances between them and the developed countries, bring about tangible results. Therefore, the dynamics of socio-economic development in developing countries are - in comparison with that of the highly-developed countries - relatively high, which translates into positive feelings on the part of the inhabitants vis-à-vis their expectations. The existence of a correlation between the improvement of the level of life and the living conditions of local and territorial communities and an increase in their members' life satisfaction may thus be indicative of the condition of territorial units, in this case placing them in the category of developing systems. For this type of environment, especially in rural areas (with an already lower level of development), a linear dependence could be expected, whereby a change in the direction of better living conditions is associated with an improved perception of one's own life and the local environment (living conditions).

\section{Methodological assumptions and characteristics of the selected communes}

Based on the presented aim of this article, three research questions were formulated:

1. What is the level of subjective quality of life of the rural population in terms of specific aspects of the individuals' lives?

2. What is the level of subjective quality of living, i.e., the perception of particular areas of the functioning of the commune?

3. Is there a relationship, and if so, what is the relationship, between the subjective quality of life and objective quality of living, analysed from the perspective of communes with different levels of socio-economic development?

The answers to these posed questions will be worked out based on the research material gathered in the project "Models of management and the determinants of their functioning in rural communes", financed by the National Science Centre, Poland (UMO-2014/14/E/HS6/00398). ${ }^{3}$

The study adopted a multi-stage selection process. The starting point was a comparative analysis of all seventeen provinces (voivodeships) in Poland (selection at the provincial level) in terms of their level of socio-economic development (based on the CSO data for 2015). Then, assuming that the cases, which are not characterized by extreme values of the variables (attributes), are best suited for deriving broader generalizations, one province characterized by average values of the indicators of development was selected from the set. Selecting one province ensures that the condition of internal homogeneity (Rosner, 2010:12) is met: all the local communes operate in a similar environment shaped by the same regional policy (provincial authorities, marshals, etc.). Hence, the first stage of analysis was used to select from among all Polish voivodeships the one which, due to the value of the indicator of socio-economic development, would occupy a position as close as possible to the average calculated for the entire set. For this purpose, a synthetic index was used which allowed for the inclusion of multiple variables ${ }^{4}$, preparation of the ranking structure and division of communes into more homogeneous groups from

\footnotetext{
${ }^{3}$ This project, implemented in the years 2015-18 had a wider scope, but we will concentrate on the aspects of quality of life and quality of living in the surveyed rural collectives.

4 The index includes variables for the voivodeship showing: the economic situation of the population; economic activity; the socio-demographic situation of the population; and the education of the legislative authorities.
} 
the perspective of their socio-economic development. The taxonomy of Hellwig's development indicator was used as a tool to visualize the level of development (Wierzbicka, Żółtaszek, 2015, Olejniczak $\left.2012^{5}\right) \cdot{ }^{6}$ The values of the indicator that were the most similar to the average were obtained for the Łódzkie and Podkarpackie voivodeships. It was then decided to choose the voivodeship (Łódzkie) located in the central part of Poland?.

Another element of the case selection (at the local commune level) was determination of the level of development of the rural communes in the selected province. For this purpose, synthetic indicators of socio-economic development were constructed (based on the data of CSO 2015), ${ }^{8}$ also using the taxonomy proposed by Hellwig. This made it possible to divide the 133 communes in the Łódzkie voivodeship into three groups, i.e., those with a low, medium or high level of development.

Next, six communes were randomly selected, i.e., two with a low level of development: Strzelce Wielkie (0.077) and Wielgomłyny (0.085); two characterized by a medium level of development: Widawa (0.088) and Godzianów (0.093); and two with the high level of development: Zgierz (0.125) and Nieborów (0.098). In these communes, a survey of the inhabitants (a total of 700 inhabitants) was conducted at the turn of October and November 2015. The sample size for each commune was selected in proportion to its size and reflected the structure of the adult population aged 18-70: Strzelce Wielkie - 104 persons, Nieborów - 131, Wielgomłyny - 104, Widawa - 113, Godzianów - 100, Zgierz - 148.

The communes selected for the study differed in many ways, including within the group with a similar level of development. For example, units with high values of partial variables representing economic aspects had lower socio-demographic characteristics, and vice versa. In addition, one of the important diversification criteria seemed to be the location within the voivodeship and the distance from large cities, especially from the capital of the region (Łódź).

Undoubtedly, among the randomly selected local government units, the suburban commune of Zgierz (located in the immediate vicinity of the region's capital) was characterized by the highest level of socio-economic development. It is also the largest unit in the study in terms of population. Its dominant functions include agriculture and housing. Due to its location in the vicinity of the Łódź agglomeration and attractive natural areas, the commune has been characterized by positive net migration for many years. Although the economic activity in this area is relatively high, the commune does not have a social infrastructure that fully meets the needs of the residents. The shortcomings relating to the offer of local services are complemented by the neighbouring towns. Another selected commune was Nieborów. Nieborów was among the group of communes with the highest socio-economic development level, but it did not reach such remarkable parameters as the commune of Zgierz mentioned above. Nieborów is a strongly urbanized rural commune located in the outskirts of the voivodeship, but within a well-developed area between two large metropolises of Poland: Warsaw and Łódź. This area has for many years been characterized by high parameters of development (Marks 2006). The commune boasts outstanding landscape features and cultural assets (e.g., a restored palace acting as a museum is unique on a national scale). The attractiveness of nature and the small distance from the capital are among the leading reasons for Nieborów's continued positive migration balance. Thus, the dominant functions in Nieborów are residential and agricultural functions.

\footnotetext{
${ }^{5}$ Focused on the development level of rural municipalities in the Lower Silesian Voivodeship in view of their income structure.

${ }^{6}$ It takes values within the range $[0,1]$. The higher the value, the closer the examined object is to the pattern and the better the situation. A score close to zero means a very unfavourable situation.

${ }^{7}$ The level of socio-economic development of the selected province as compared to all provinces is average (0.273), and the value of the Hellwig's measure for the Łódzkie voivodeship slightly exceeds the average value for Poland (0.244) and the median (0.208).

8 The index takes into account the available variables for communes showing: economic situation of the population, economic activity and socio-demographic situation of the population, and education of the legislative authorities.
} 


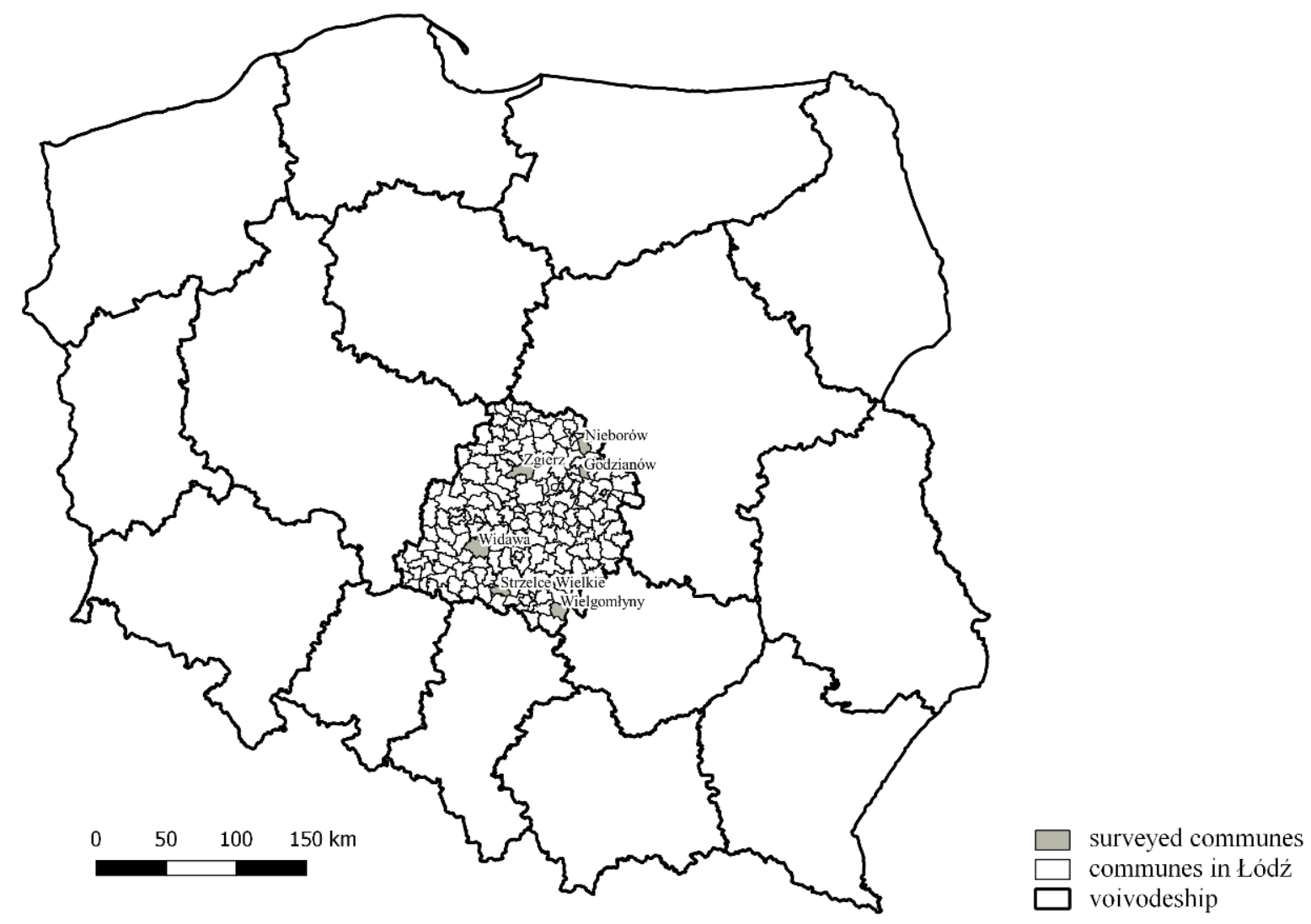

Fig 1. Location of the case study communes (by Marcin Feltynowski).

The second group is characterized by an average level of socio-economic development. Godzianów is one of the smallest communes in the province in terms of area and population, and is located peripherally, with a predominantly agricultural function. Its good soil promotes the development of agriculture, especially large-scale agriculture. The commune has been struggling for years with the problem of depopulation. Its relatively large budget comes in part from the personal income taxes of persons living in Godzianów who are often employed in Warsaw, an arrangement facilitated by the relatively short distance to the capital. In contrast to Godzianów, Widawa is one of the largest communes included in this research in terms of area. It is distinguished by a rich historical past. Its location on a trade route once favoured its intensive development, to the extent that in the years 1388-1870, it served the function of a town. At present, however, the dominant function is agriculture. The relatively large distance from major cities and the negative population growth means that today this commune is becoming gradually depopulated.

The last group consists of communes with the lowest parameters of socio-economic development. Out of this set, the communes of Strzelce Wielkie and Wielgomłyny were randomly selected. Both administrative units are located not far from each other, but on the periphery of the province and far away from major cities. They are characterized by nature values (so far totally unused) and good conditions for the development of agriculture. Although the agricultural function dominates in both these areas, it is based on low-income small farms. Both communes face the problem of depopulation. An important difference observed between them is connected with their different financial policies. Strzelce Wielkie runs a cost-effective but sustainable financial economy, balancing expenditures with revenues, slightly supporting its development with EU resources. On the other hand, Wielgomłyny has been taking high loans for many years, and has lately allocated them to finance current operations rather than investment activity. The basic data of these communes - supplementary to this description - are included in Table 1. 
Tab 1. Characteristics of the examined communities. Source: Authors' own elaboration

\begin{tabular}{|c|c|c|c|c|c|c|c|}
\hline \multicolumn{2}{|c|}{ CHARACTERISTICS } & Nieborów & Zgierz & Wielgomłyny & Strzelce & Widawa & Godzianów \\
\hline \multirow{4}{*}{$\begin{array}{l}\text { BASIC } \\
\text { DATA }\end{array}$} & Population (in thousands) & 9.5 & 13.5 & 4.7 & 4.7 & 7.5 & 2.6 \\
\hline & Population density & 91 & 68 & 38 & 60 & 42 & 59 \\
\hline & $\begin{array}{l}\text { Village administrators' } \\
\text { offices }\end{array}$ & 19 & 40 & 18 & 14 & 41 & 6 \\
\hline & Net migration rate & + & ++ & - & - & - & - \\
\hline \multirow{3}{*}{ 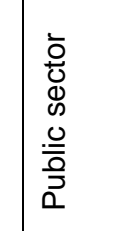 } & $\begin{array}{l}\text { Budget expenditures } \\
\text { (per capita in PLN) }\end{array}$ & 2,584 & 3,110 & 3,052 & 4,164 & 2,944 & 3,612 \\
\hline & Voit/Council & $\begin{array}{c}\text { Old } \\
\left(7^{\mathrm{h}} \text { term }\right) \\
/ 15\end{array}$ & $\begin{array}{l}\text { New } \\
/ 15\end{array}$ & $\begin{array}{c}\text { Old } \\
\left(7^{\mathrm{h}} \text { term) }\right. \\
/ 15\end{array}$ & $\begin{array}{l}\text { New } \\
/ 15\end{array}$ & $\begin{array}{l}\text { New } \\
/ 15\end{array}$ & $\begin{array}{c}\text { Old } \\
\left(2^{\text {nd }} \text { term }\right) \\
/ 15\end{array}$ \\
\hline & Public institutions & 23 & 28 & 11 & 12 & 18 & 6 \\
\hline 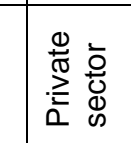 & $\begin{array}{l}\text { Companies in the REGON } \\
\text { register /per 10,000 } \\
\text { inhabitants }\end{array}$ & 615 & 1,071 & 508 & 444 & 619 & 674 \\
\hline \multirow{6}{*}{$\begin{array}{l}\overline{0} \\
\frac{0}{0} \\
\Phi \\
\frac{\pi}{0} \\
\frac{\pi}{0} \\
\dot{0}\end{array}$} & Volunteery Fire Fighters & 11 & 11 & 11 & 9 & 9 & 6 \\
\hline & Community Sports Clubs & 4 & 10 & 2 & 2 & 10 & 2 \\
\hline & Agricultural circles & 6 & 3 & - & - & 4 & 6 \\
\hline & Associations /Foundations & 5 & 15 & 4 & 2 & 8 & 2 \\
\hline & $\begin{array}{l}\text { Rural Women } \\
\text { Associations }\end{array}$ & 12 & 12 & 10 & 1 & 6 & 1 \\
\hline & $\begin{array}{l}\text { Voter turnouts (local } \\
\text { elections) }\end{array}$ & $50 \%$ & $54 \%$ & $62 \%$ & $59 \%$ & $59 \%$ & $65 \%$ \\
\hline
\end{tabular}

\section{Subjective Quality of life}

For a further justification for conducting research on the subjective quality of life, we can refer to the works of American psychologist, Angus Campbell. He drafted a critical analysis of research and theoretical studies, pointing out that they use only objective indicators as a source of knowledge about the quality of life of the society. He claimed that - based on the available statistics - we are not able to answer the question: "How do people live?" He argues that when describing the living conditions of the population, it can be assumed that they impact the assessment of life, but cannot constitute the sole basis for this assessment (Campbell, 1976: 118). Other researchers also suggest that in investigations into the quality of life, both subjective and objective dimensions must be taken into account, namely satisfaction with life as well as the external conditions (quality of living) that shape it (D'Agostini and Fantini 2008: 488). It is also noted that a relatively low objective quality of life does not necessarily mean a lack of satisfaction with life on the part of the inhabitants of a given local system. The discrepancy between the objective and subjective quality of life in the context of international comparisons has also been discussed by M. Shucksmith, S. Cameron, T. Merridew and F. Pichler (2009: 1288). Limited research conducted in the slums of Calcutta showed that the inhabitants' satisfaction with their lives was higher than one might have expected, given the conditions in which they function (Biswas-Diener, Diener, 2001).

This paper will thus present the subjective dimension of quality of life reported by the inhabitants of the examined rural communities (administrative communes). According to M. Rapley (2003: 28 ), it is generally assumed that the notion of quality of life is a multidimensional construct and it refers to the individual's expectations with respect to chosen dimensions of life. Based on this observation, the researchers decided to apply one of the most popular methods for measuring quality of life. It is based on the quantification of a number of variables which were used to describe the components of quality of life, followed by an aggregation of the scores obtained, thus revealing the overall assessment (the subjective quality of life index). R. Cummins (1996) analysed those dimensions of quality of life considered as most important from the point of view of the respondents. He found that most of them refer to five basic notions, being: emotional wellbeing; health; family and social relationships; material well-being; professional work or other forms of activity. 
The assessment of specific aspects of an individual's life in this study was made using an 11- point scale, where 0 meant total dissatisfaction and 10 - full satisfaction. In this case, the research covered issues related to the family life of the respondents, interpersonal relations, work performed, education, financial situation, housing conditions, prospects for the future, health, and ways of spending free time.

As can be seen, the inhabitants of the examined rural communes were generally satisfied with the individual elements of their life. The source of life's greatest satisfaction were their own children, with over $80 \%$ of the respondents satisfied or very satisfied with their children, and the highest degree of satisfaction being associated with this aspect. Other important sources of satisfaction were with their: marriage/relationship, family relationships, and contacts with friends, followed by their current work. The respondents were the least satisfied with their own financial situation, the money spent on food, and their prospects for the future.

Tab 2. Respondents' evaluation of the subjective quality of their life. Source: Authors' own elaboration

\begin{tabular}{|c|c|c|c|c|c|c|c|}
\hline & 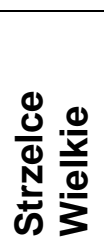 & $\begin{array}{l}3 \\
\frac{3}{0} \\
\frac{0}{0} \\
\frac{0}{2}\end{array}$ & $\frac{\substack{0 \\
\frac{\pi}{0} \\
\frac{0}{3}}}{3}$ & 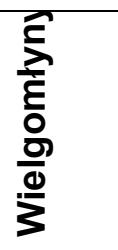 & $\begin{array}{l}.3 \\
\frac{3}{0} \\
\frac{1}{N} \\
\frac{N}{0} \\
0 \\
0 \\
0\end{array}$ & $\frac{\mathbf{N}}{\stackrel{\mathbf{d}}{\sigma}}$ & $\begin{array}{l}\text { Average } \\
\text { grade }\end{array}$ \\
\hline $\begin{array}{l}\text { Contacts with } \\
\text { family members }\end{array}$ & 8.65 & 8.99 & 9.05 & 8.14 & 8.35 & 9.79 & 8.90 \\
\hline $\begin{array}{l}\text { One's own } \\
\text { marriage/ } \\
\text { relationship }\end{array}$ & 8.43 & 8.99 & 8.84 & 8.22 & 8.27 & 9.38 & 8.73 \\
\hline One's own children & 9.45 & 9.82 & 9.54 & 9.25 & 8.89 & 9.79 & 9.50 \\
\hline $\begin{array}{l}\text { Contacts with } \\
\text { friends }\end{array}$ & 7.97 & 8.44 & 8.38 & 7.40 & 7.73 & 9.12 & 8.25 \\
\hline $\begin{array}{l}\text { Contacts with } \\
\text { neighbours }\end{array}$ & 7.46 & 7.29 & 7.54 & 6.34 & 6.71 & 8.12 & 7.30 \\
\hline $\begin{array}{l}\text { Currently } \\
\text { performed work }\end{array}$ & 7.34 & 7.44 & 7.29 & 6.74 & 6.99 & 8.04 & 7.34 \\
\hline $\begin{array}{l}\text { Financial situation } \\
\text { in the household }\end{array}$ & 7.14 & 7.21 & 6.85 & 6.59 & 6.51 & 6.98 & 6.90 \\
\hline $\begin{array}{l}\text { Money that can be } \\
\text { spent on food every } \\
\text { month }\end{array}$ & 6.92 & 6.97 & 6.79 & 6.41 & 6.32 & 6.71 & 6.70 \\
\hline Housing conditions & 7.48 & 7.98 & 7.36 & 7.09 & 7.23 & 8.03 & 7.57 \\
\hline $\begin{array}{l}\text { Prospects for the } \\
\text { future }\end{array}$ & 7.03 & 7.12 & 6.73 & 6.72 & 6.50 & 7.28 & 6.92 \\
\hline Life achievements & 7.21 & 7.59 & 7.21 & 6.97 & 6.81 & 7.70 & 7.29 \\
\hline Education & 7.16 & 7.34 & 6.79 & 6.54 & 6.72 & 7.34 & 7.01 \\
\hline Health condition & 7.40 & 7.93 & 7.16 & 6.99 & 7.31 & 8.03 & 7.52 \\
\hline Mental health & 7.69 & 8.40 & 7.72 & 7.13 & 7.47 & 8.61 & 7.91 \\
\hline $\begin{array}{l}\text { Way of spending } \\
\text { free time }\end{array}$ & 7.43 & 7.81 & 7.39 & 6.90 & 6.99 & 8.20 & 7.51 \\
\hline Average & 7.65 & 7.95 & 7.64 & 7.16 & 7.25 & 8.21 & $x$ \\
\hline
\end{tabular}


In order to investigate the general level of the subjective quality of life, a synthetic scale of quality of life was constructed including all the emphasized items ${ }^{9}$. The reliability of the scale was verified using Cronbach's alpha method. The value of the factor was 0.968 in this case, so the constructed scale should be regarded as a reliable measurement tool. The sum of the values of the variables, each of which had been previously standardized, created a synthetic index. The minimum value of the index is -32.58 and the maximum value is 25.66 . The average value of satisfaction with particular areas of the respondents' lives in the whole examined population was 1.25. This result is indicative of rather ambiguous evaluations of their place of residence by the inhabitants of the researched communes.

Tab 3. Average values of the synthetic quality of life index. Source: Authors' own elaboration

\begin{tabular}{|l|r|r|r|}
\hline Commune & \multicolumn{1}{|l|}{ Average } & \multicolumn{1}{|l|}{$\begin{array}{l}\text { Standard } \\
\text { deviation }\end{array}$} & N \\
\hline Nieborów & 5.853 & 11.432 & 63 \\
\hline Zgierz & 5.590 & 9.361 & 71 \\
\hline Widawa & 0.900 & 12.507 & 69 \\
\hline Strzelce Wielkie & 0.006 & 13.150 & 65 \\
\hline Wielgomłyny & -2.485 & 9.255 & 47 \\
\hline Godzianów & -5.488 & 12.478 & 47 \\
\hline Overall & 1.252 & 12.072 & 363 \\
\hline
\end{tabular}

Interesting results are provided by a comparison of the average scale values for individual communes. Thus, the differences between the communes with the highest score for subjective quality of life (Nieborów 5.85 and Zgierz 5.59) and the communes with the inhabitants' lowest recorded level of satisfaction with certain spheres of life (Godzianów -5.48) was more than 10 points, which should be considered as a significant difference. The communes with a higher index of subjective quality of life (Nieborów, Zgierz) manifested a tendency to offer rather positive assessments, while the communes with the lowest scores (Godzianów, Wielgomłyny) showed the opposite tendency. Interestingly, also in this case, the effect of scale was noticeable. In the larger communes (Zgierz and Nieborów), a higher level of the feeling of welfare was observed than in the smaller communes. The lowest level of satisfaction with life was declared by residents of the Godzianów commune, the smallest of the examined local communes.

\section{Subjective quality of living in the community}

The perceived quality of living in the community was investigated by determining the level of satisfaction of the inhabitants with certain elements of the commune. The availability and also the performance of specific institutions (such as health care centres, education institutions, the labour market, public services, cultural institutions and institutions of power and management) are largely determinative of the quality of living in the community. The literature also emphasizes the importance of inhabitants' attachment to the local community (Brehm, Eisenhauer, and Krannich 2004) and their desire to remain as its members, thereby countering outward migration trends. Institutions become one of the basic elements of the living environment and - as regulators of both individual and collective behaviours - they meet the needs and limit the range of uncertainty that exists in social life (Schotter 1981).

The number and quality of local facilities and amenities make up an important factor influencing the assessment of one's place of residence as a convenient, attractive place to live (or not), providing an indicator of the community's development (Floryda, 2002, Besser, Recker, \& Parker, 2009). Studies that have tackled the problem of quality of living (QOL) have usually focused on the analysis of objective indicators describing the living conditions of given local systems

\footnotetext{
${ }^{9}$ Due to the need to include all variables in the analysis, 462 cases were removed because of data deficiencies in at least one variable; (i.e., not applicable, I do not have an opinion).
} 
(D'Agostini et. al., 2008). In this article, however, the problem of their subjective assessment was explored, which resulted in determining the level of satisfaction of the residents with particular aspects of the functioning of their communes. Evaluation of individual components of living and living conditions in the commune was made using an 11-point scale, where 0 meant total lack of satisfaction, and 10 - full satisfaction. The researchers' interest was focused on satisfaction with areas such as management of the commune, the activity of local institutions (police, health care, education, culture and entertainment) and local businesses, as well as the quality and aesthetics of communal infrastructure. Diagnosing the satisfaction with various aspects of life encompassed analysis of a total of 17 aspects.

Tab 4. Assessment of the subjective quality of living of the respondents in the examined communes. Source: Authors' own elaboration

\begin{tabular}{|c|c|c|c|c|c|c|c|}
\hline & 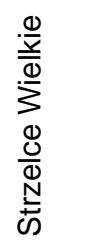 & $\begin{array}{l}3 \\
.00 \\
\frac{0}{0} \\
\frac{0}{2}\end{array}$ & $\begin{array}{l}\frac{\pi}{3} \\
\frac{\pi}{0} \\
\frac{0}{3}\end{array}$ & 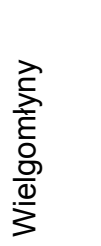 & $\begin{array}{l}3 \\
\frac{3}{0} \\
\frac{\pi}{\pi} \\
\frac{\pi}{N} \\
\frac{0}{0} \\
0\end{array}$ & $\frac{N}{\frac{N}{0}}$ & Average \\
\hline Functioning of health care institutions & 6.63 & 6.98 & 5.81 & 6.45 & 6.16 & 5.28 & 6.20 \\
\hline $\begin{array}{l}\text { Functioning of educational institutions in the } \\
\text { commune }\end{array}$ & 7.23 & 7.62 & 6.54 & 7.24 & 7.56 & 7.52 & 7.30 \\
\hline $\begin{array}{l}\text { Functioning of cultural and entertainment } \\
\text { institutions }\end{array}$ & 6.75 & 6.58 & 6.02 & 6.52 & 6.24 & 5.81 & 6.30 \\
\hline Quality of the environment & 7.89 & 8.49 & 7.66 & 7.78 & 7.92 & 8.82 & 8.15 \\
\hline Possibility of doing business in the commune & 7.06 & 7.20 & 6.54 & 6.51 & 6.70 & 6.50 & 6.74 \\
\hline State of roads in the commune & 6.24 & 6.08 & 5.84 & 5.46 & 5.52 & 6.52 & 5.98 \\
\hline Cleanliness of public places & 7.17 & 7.35 & 6.82 & 6.40 & 6.95 & 7.71 & 7.11 \\
\hline Activities of the local parish and priests & 7.19 & 7.16 & 6.76 & 5.98 & 6.82 & 8.38 & 7.11 \\
\hline Assortment of local shops & 6.92 & 6.75 & 6.45 & 5.90 & 6.69 & 5.91 & 6.43 \\
\hline $\begin{array}{l}\text { Conditions for rest and recreation in the } \\
\text { commune }\end{array}$ & 7.14 & 7.03 & 6.57 & 6.63 & 6.18 & 6.51 & 6.68 \\
\hline Transport links in the commune & 7.28 & 6.15 & 6.19 & 5.46 & 6.03 & 4.84 & 5.93 \\
\hline Management of the commune & 7.00 & 6.75 & 6.31 & 6.45 & 6.23 & 5.77 & 6.42 \\
\hline Functioning of the local government & 6.91 & 6.40 & 5.99 & 6.30 & 6.28 & 5.68 & 6.25 \\
\hline Activity of political parties in the commune & 6.73 & 5.55 & 5.66 & 5.19 & 5.44 & 5.29 & 5.67 \\
\hline $\begin{array}{l}\text { Activity of non-governmental organizations in } \\
\text { the commune }\end{array}$ & 6.84 & 5.93 & 5.89 & 5.42 & 5.56 & 5.43 & 5.90 \\
\hline $\begin{array}{l}\text { Possibility of influencing important issues in } \\
\text { the commune }\end{array}$ & 6.83 & 6.14 & 5.29 & 6.15 & 5.54 & 5.49 & 5.94 \\
\hline State of safety in the place of residence & 7.91 & 8.24 & 7.64 & 6.63 & 7.12 & 6.80 & 7.37 \\
\hline Average & 7.04 & 6.85 & 6.35 & 6.26 & 6.41 & 6.37 & - \\
\hline
\end{tabular}

The respondents participating in the study presented a relatively high level of satisfaction with life in the commune. The obtained results make it possible to indicate those areas and conditions related to living, which were evaluated best and those, which were evaluated worst by the respondents. The highest level of their satisfaction is associated with the quality of the living environment. The respondents highly appreciated the functioning of educational institutions operating in the commune and the state of safety in their place of residence. A slightly lower level of satisfaction was reported with respect to the cleanliness of public places, such as squares and streets, as well as the activity of local parishes and priests. The lowest level of satisfaction, reflecting ambiguous rather than negative ratings, was recorded for local institutions such as political parties and non-governmental organizations operating in the commune, and the possibility of influencing important communal issues. The much lower number of people actually assessing the functioning of these institutions may be a result of their lack of activity in 
the community, or of the carrying out of activities invisible to the respondents. A similar level of satisfaction was also linked to the communication sphere, including the quality of roads and transport links.

The research revealed significant differences in the inhabitants' level of satisfaction with the functioning of the selected individual communes. The inhabitants of the commune of Zgierz manifested the lowest level of satisfaction, with the highest number of distinguished spheres. The worst scores were noted for communication links and the activity of cultural and entertainment institutions, and for the areas related to the management of the commune, the functioning of local political parties and non-governmental organizations, and the possibility of influencing issues important for the commune. The residents were also the least satisfied with the commercial offer of the local shops. However, they gave the highest score among the inhabitants of all the examined communes in assessing the activity of local parishes and priests and the quality of the environment.

An equally large number of the lowest scores were recorded in the commune of Wielgomłyny. The residents of this commune were least satisfied with aspects such as the quality of roads, cleanliness of local streets, squares and buildings, the activity of the parishes and priests and the state of safety. Moreover, similarly to the inhabitants of the Zgierz commune, they were least satisfied with the assortment of local shops as well as the activity of political parties and nongovernmental organizations.

In the case of the Strzelce Wielkie commune, a high level of satisfaction was recorded with the greatest number of aspects. The inhabitants of this commune assessed most favourably the transportation links and the way of managing the commune, as well as those areas which were the subject of the lowest ratings of the inhabitants of Wielgomły and Zgierz communes, i.e., the functioning of political parties and non-governmental organizations and the possibility of influencing the decisions taken in the commune.

In the commune of Nieborów, the respondents were least satisfied with the state of safety, the quality of the natural environment, and the functioning of educational as well as cultural and entertainment institutions.

The inhabitants of the commune of Widawa were the most moderate in their evaluations, although they did negatively assess the quality of the natural environment and the functioning of educational institutions in the commune, i.e., those spheres that were given the highest satisfaction scores by the remaining respondents.

Tab 5. Average values of the synthetic quality of living index. Source: Authors' own elaboration

\begin{tabular}{|l|r|r|r|}
\hline Commune & Average & Standard deviation & N \\
\hline Nieborów & 3.899 & 19.017 & 23 \\
\hline Strzelce Wielkie & 3.713 & 11.799 & 52 \\
\hline Widawa & -1.244 & 14.432 & 55 \\
\hline Godzianów & -3.142 & 15.525 & 31 \\
\hline Zgierz & -3.351 & 12.093 & 44 \\
\hline Wielgomłyny & -4.354 & 12.786 & 33 \\
\hline Total & -0.73 & 14.158 & 238 \\
\hline
\end{tabular}

As in the case of investigating the overall level of subjective quality of life, for the analysis of the subjective quality of living, a synthetic Subjective Quality of Living Index was constructed (containing all of the above variables) ${ }^{10}$. Partial items were standardized and then aggregated to form a scale for which Cronbach's alpha was 0.964 . The value of the coefficient should be regarded as highly satisfactory. The average satisfaction with individual elements of living was - 0.73, while the minimum value equalled -40.9 , and the maximum equalled 33.7.

\footnotetext{
${ }^{10}$ Due to the need to include all variables in the analysis, 338 cases were removed because of data deficiencies in at least one variable (i.e., not applicable, I do not have an opinion).
} 
The comparative analyses for individual communes lead to the general conclusion that the satisfaction of the inhabitants of the majority of the examined communes is slightly below average. In the case of respondents from two communes (Nieborów and Strzelce Wielkie), their level of satisfaction with living exceeded the average values by four times. Large variations (up to 10 points) in the assessment of satisfaction with the place of residence are visible between the most satisfied residents and those that assessed their living conditions in the most negative way, namely the communes of Wielgomłyny, Godzianów, and Zgierz.

In referring to the significance of the level of development of the commune described on the basis of objective indicators, interesting relationships could be observed for the perception of living conditions and the level of satisfaction with them. These correlations were most evident in the communes with the lowest and highest levels of development and of SQOL among the investigated communes. Firstly, in the commune of Zgierz, which was characterized by the highest level of socio-economic development, the lowest level of quality of living was noted in the opinion of the respondents. This paradox can be described after Noll as a dissonance, or "dilemma of dissatisfaction" (H. Noll 1984: 25, as cited in Rapley 2003: 31). It characterizes people whose life aspirations are disproportionately high in the context of the objective, relatively good conditions in which they are located. Similar results were obtained by Paweł Starosta comparing the objective conditions of living and the level of satisfaction with residence in the case of inhabitants of the post-industrial cities of Central and Eastern Europe (Starosta 2016). Secondly, in the commune with the worst developmental parameters - Strzelce Wielkie, the highest level of satisfaction was noted in certain areas of functioning of the commune and the conditions prevailing in it. This relationship was defined by Noll as an adaptation resulting from rationalization, which leads to a positive perception of the object of assessment (in this case the place of residence) in the situation where one is unable to change it.

\section{Relationship between quality of life and quality of living in the studied communes}

The last of the research questions concerned the relationship between the quality of life and quality of living in the investigated communes. For this purpose, a regression analysis was applied. Despite confirming the statistically significant relationship $(p=0.000)$ between the cooccurrence of the two studied phenomena, the coefficient $r^{2}$ of 0.145 indicates a relatively weak correlation. The Beta coefficient of 0.380 confirms the weak positive strength of these relationships.

Nevertheless, interesting relationships between the two variables can be observed within individual communes.

Tab 6. Parameters of regression analysis in individual communes. Source: Authors' own elaboration

\begin{tabular}{|l|c|c|c|}
\hline Commune & $\mathrm{R}^{2}$ & Beta coefficient & Level of significance \\
\hline Strzelce Wielkie & $\mathbf{0 . 5 0 1}$ & $\mathbf{0 . 7 0 8}$ & $\mathbf{0 . 0 0 0}$ \\
\hline Nieborów & 0.387 & 0.622 & 0.023 \\
\hline Wielgomłyny & 0.357 & 0.598 & 0.019 \\
\hline Godzianów & $\mathbf{0 . 2 7 8}$ & $\mathbf{- 0 . 5 2 8}$ & 0.020 \\
\hline Widawa & 0.156 & 0.395 & 0.021 \\
\hline Zgierz & 0.057 & 0.153 & 0.240 (non-significant) \\
\hline
\end{tabular}

In five of the six territorial units examined, the analysis model showed the influence of the sense of satisfaction with living in the commune on the residents' satisfaction with their quality of life. The relationships between the two variables in these communities were characterized by a certain variability however, and the search for explanations of this variability will focus on the specific nature and the socio-economic level of development of the communes.

In the case of Strzelce Wielkie commune, the Beta coefficient equalling 0.708 suggests that the existing relationship is strongly positive. In four of the other communes, the relationship between the two variables is somewhat weaker. The communes of Godzianów and Strzelce 
Wielkie are characterized by the lowest level of socio-economic development (among the studied areas). They perform similar agricultural functions and are located peripherally in relation to the voivodeship's capital city. In these communes, although the subjective quality of life is assessed as average, the perception of the quality of living is quite different. The Strzelce Wielkie commune is characterized by a high average of satisfaction, while the Wielgomłyny commune has the lowest average. It seems that the explanations for these results are to be sought in partial variables, or such that were not taken into account in our study. Nieborów, on the other hand, is characterized by the highest (in terms of the examined communes) indicators of satisfaction as far as both quality of life and quality of living are concerned. In this case, the interpretation should also be sought in the specificity of the commune. It is inhabited by a relatively large number of new residents (from the city) who have consciously chosen this place because of its living conditions (mainly nature) and its proximity to Warsaw, where they often find employment. This explains why they have reasons to feel satisfaction both with their private life and the quality of living.

In the case of inhabitants of another commune (Godzianów), the negative Beta index value $(-0.528)$ suggests that as their satisfaction with the quality of their life improves, their satisfaction with living in the commune decreases. The interpretation of this result could be related to the social characteristics of the commune. It is inhabited by a population that primarily finds employment in the capital of the country (Warsaw) and has quite high earnings, as evidenced by the relatively high share of the revenues of the commune coming from personal income tax. The living conditions in this smallest of our selected commune, characterized by very low urbanization and with agriculture as the dominant function, may seem very unsatisfactory to them, especially compared to metropolises that are well known to the respondents. Therefore, their expectations towards their own place of residence may be excessively high.

\section{Conclusions}

The subject of our interest was the quality of life and quality of living of rural residents. In particular, the core focus of the study was on the relationship between these concepts occurring in rural communities, which differ in terms of their level of socio-economic development. The presented analyses lead to several main conclusions.

The first is that the rural residents who participated in the study were characterized by a relatively high satisfaction with their own lives. The results obtained are confirmed by the research on the subjective sense of well-being and satisfaction of life conducted on a nationwide sample. They indicated a high level of satisfaction $(80.6 \%)$ of the rural population with life in general, exceeding the national average (78.4\%) (Public Opinion Research Center CBOS 2013, 2016; Rural Poland 2016). The main source of satisfaction with life in the case of our respondents was the family sphere. The importance of relationships and family ties for the quality of human life has already been recognized in the international literature (Cummins 1996, Bukenya et al., 2003).

The biggest source of dissatisfaction of the villagers was with their financial situation. Despite the significant increase in income experienced by the rural population after accession to the European Union structures, the income of rural residents is still lower (by about $20 \%$ ) than the average in the country and lower (by about 29\%) than in the cities. This indicates the relatively weak financial condition of the rural population in Poland. Researchers still point to the problem of extreme poverty. Over $60 \%$ of the total number of persons living below the poverty line in Poland are villagers, and the risk of this problem is higher than the average in the European Union (Zegar et al. 2016). Although their objective financial condition is the reason for the lowest satisfaction of the respondents, the average subjective rating of this aspect was surprisingly high. The explanation for the relatively high subjective evaluation of their financial situation (with reference to the level of income) may be rooted in the rather low life aspirations of the rural population (Zegar et al., 2016) and comparisons of the current situation with the period of systemic transformation, which brought about a significant deterioration of the financial situation of the rural population in Poland.

However, there was a significant difference in the quality of life of rural residents, defined as the aggregate value of the partial variables (the subjective quality of life index) in communes with 
different levels of socio-economic development. In particular, a clear correlation was observed in more developed communes. We might put forward a general statement that the higher the level of development of the community, the higher the perceived quality of life. This could indicate the limited importance of objective conditions of life for the life satisfaction of the respondents. Nevertheless, as stated earlier, the relationship between the conditions in which an individual lives and his/her quality of life is not linear.

The second conclusion comes from the analysis of subjective quality of living. The examined residents overall positively assessed the conditions of living in their community. According to multiannual, nationwide CBOS research, the attractiveness of living in the countryside, as compared to the 1990s, has definitely increased, similar as with the satisfaction with living in rural areas. The reasons most often cited include: peace and quiet, commitment to the countryside, and environmental assets (CSO, 2015). Similar trends were noted in the responses of the rural residents questioned in this study. They were happy, first and foremost, with the natural environment and their security.

The lowest level of satisfaction with living in the rural communes was associated with such aspects as technical infrastructure, transport links, the activity of NGOs and political parties, and the possibility of exerting an influence on the commune's policy. These problems have remained unresolved in rural areas for many years and are important barriers to their development (Cf. Rosner, 2002). Based on the presented data, however, it is difficult to find confirmation whether the problem is accessibility or the quality of the local offer of non-governmental organizations, but it is known that the activities of these entities are insignificant and often informal (Halamska 2008). Despite crucial differences in the assessment of the individual elements of living in the examined communes, the analysis does not allow to determine the relationship between the level of development of the commune and the subjective level and the quality of living in it. Explanations should be sought each time in the specificity of the particular commune and its developmental conditions.

Thirdly, it is difficult to specify general correlations that would clarify the relationship between the quality of life and quality of living in rural communities. The regression analysis confirmed the weak link between these two phenomena. In spite of this, in-depth analyses showed that among the six investigated territorial units, in five, the analysis model showed a statistically significant influence (of varying intensity) of the quality of living in the commune on the quality of life of the inhabitants. However, no similarities (in terms of strength and direction) of the relationships in communes of similar levels of development can be seen. This might be explained by the specificity of each separate territorial commune.

The final conclusion confirms the thesis of a high heterogeneity and diversity of rural communes in Poland, even within a socially, culturally and economically coherent area of a voivodeship. It therefore seems justified to search for the determinants of quality of life and quality of living as inherent in the local resources, (Stedman, Parkins, Beckley, 2004), its economic structure (especially agricultural production), natural environment, and in the involvement of local institutions, especially self-governmental authorities (Hooks, Lobao, Tickamyer, 2016).

\section{Academic references}

[1] Adamska, H. (2006). Jakość życia jako jeden z ważnych elementów zrównoważonego rozwoju obszarów wiejskich. Zeszyty Naukowe Akademii Rolniczej we Wrocławiu. Rolnictwo 87, 25-30.

[2] Bański, J. \& Pantyley, V. (2013). Warunki życia we wschodniej Polsce według regionów i kategorii jednostek osadniczych. Nierówności społeczne a wzrost gospodarczy 34, 107123.

[3] Besser, T. L., Recker, N. \& Parker, M. (2009). The impact of new employers from the outside, the growth of local capitalism, and new amenities on the social and economic welfare of small towns. Economic development quarterly, 23(4), 306-316. 
[4] Biswas-Diener, R. \& Diener, E. (2001). Making the best of the bad situation: Satisfaction in the slums of Calcutta, Social Indicators Research 55, 329-352. DOI: 10.1023/A:101090502.

[5] Borys, T. \& Rogala, P. (2008). Jakość życia na poziomie lokalnym - ujęcie wskaźnikowe. Warszawa: UNDP.

[6] Borys, T. (2001). Jakość życia jako kategoria badawcza i cel nadrzędny. In Wachowiak A., ed., Jak żyć, wybrane problemy jakości (pp. 17-41). Poznań: Wydawnictwo Fundacji „Humaniora”.

[7] Brehm, J., Eisenhauer, B. \& Krannich, R. (2004). Dimensions of community attachment and their relationship to well-being in the amenity-rich rural west. Rural Sociology 69, 405-429. DOI: $10.1526 / 0036011041730545$.

[8] Bukenya, J. O., Gebremedhin, T. G. \& Schaeffer, P. V. (2003). Analysis of quality of life and rural development: Evidence from West Virginia data. Growth and Change, 34(2), 202-218. DOI: 10.1111/1468-2257.00214.

[9] Campanera, J. \& Higgins, P. (2011). The Quality of Life in English Local Authority Areas. Local Government Studies 37(2), 145-169. DOI: 10.1080/03003930.2011.555081.

[10] Campbell, A. (1976). Subjective measures of well-being. American Psychologist 31(2), 117124.

[11] Costanza, R., Fisher, B., Ali, S., Beer, C., Bond, L., Boumans, R., Danigelis, N. L., Dickinson, J., Elliott, C., Farley, J., Gayer, D. E., MacDonald Glenn, L., Hudspeth, T. R., Mahoney, D. F., McCahill, L., McIntosh, B., Reed, B., Turab Rizvi, A., Rizzo, D. M., Simpatico, T. \& Snapp, R. (2008). An integrative approach to quality of life measurement, research, and policy. Surveys and Perspectives Integrating Environment and Society 1(1), 17-21.

[12] Cummins, R. A. (1996). The domains of life satisfaction: An attempt to order chaos. Social Indicators Research 38(3), 303-328.

[13] Czapiński, J. (2012). Individual quality of life. In: Czapiński, J., Panek, T., eds., Social diagnosis 2011. The objective and subjective quality of life in Poland [Research report], Warsaw: The Council for Social Monitoring.

[14] Czapiński, J. (2002). Szczęśliwy człowiek w szczęśliwym społeczeństwie? Zrównoważony rozwój, jakość życia i złudzenie postępu. Psychologia Jakości Życia 1, 9-34.

[15] D'Agostini, L. R. \& Fantini, A. C. (2008). Quality of life and quality of living conditions in rural areas: distinctively perceived and quantitatively distinguished. Social Indicators Research 89(3), 487-499. DOI 10.1007/s11205-008-9245-4.

[16] Diener, E. \& Suh, E. (1997). Measuring quality of life: economic, social and subjective indicators. Social Indicators Research 40 (1), 189-216. DOI: 10.1023/A:100685951.

[17] Florida, R. (2002). The economic geography of talent. Annals of the Association of American Geographers 92(4), 743-755. 10.1111/1467-8306.00314.

[18] Frenkel, I. (2016). Population of rural areas. In: Wilkin, J. \& Nurzyńska, I., eds., Rural Poland 2016. Rural Development Report (pp. 17-51). Warszawa: Foundation for the Development of Polish Agriculture, Scholar Publishing House.

[19] Furmankiewicz, M., Janc, K. \& Macken-Walsh, Á. (2016). The impact of EU governance and rural development policy on the development of the third sector in rural Poland: A nationwide analysis. Journal of Rural Studies 43, 225-234. DOI: 10.1016/j.jrurstud.2015.12.011.

[20] Gorlach, K. \& Mooney, P. H. (1998). Polish peasants in the first years of transformation. In Pickles, J. \& Smith, A., eds., Theorizing Transition: The Political Economy of PostCommunist Transformations (pp. 248-267). London-New York: Routledge.

[21] Gorlach, K. \& Starosta, P. (2016). Farming Families in Rural Communities. In: Shucksmith, M., Brown, D. L., Argent, N., Bock, B. B., Cheshire, L., Freshwater, D., Lawrence, G., 
Rønningen, K., Schafft, K. A. \& Shortall, S., eds., International Handbook of Rural Studies (pp, 518-530). London-New York: Routledge.

[22] Halamska, M. (2008). Social capital in rural areas: a reconstruction attempt. Przegląd Socjologiczny, 57(4), 69-93.

[23] Halamska, M. (2011). The Polish Countryside in the Process of Transformation 1989-2009. Polish Sociological Review 173, 35-54.

[24] Halamska, M. (2016). The evolution of family farms in Poland: present time and the weight of the past. Eastern European Countryside 22(1), 27-51. DOI: 10.1515/eec-2016-0002.

[25] Heffner, K. \& Rosner, A. (2005). Spatial variations in economic development of rural areas in Poland. In: Zawalińska, K., ed., Rural Development in Enlarged European Union. Warszawa: Institute of Rural and Agricultural Development Polish Academy of Science.

[26] Heffner, K., Klemens, B. (2012). Warunki życia i aktywność społeczno-gospodarcza mieszkańców na obszarach wiejskich (na przykładzie województwa opolskiego). Barometr Regionalny 30(4), 81-88.

[27] Hooks, G., Lobao, L. M. \& Tickamyer, A. R. (2016). Spatial Inequality and Rural Areas. In Shucksmith, M., Brown, D. L., Argent, N., Bock, B. B., Cheshire, L., Freshwater, D., Lawrence, G., Rønningen, K., Schafft, K. A. \& Shortall, S., eds. International Handbook of Rural Studies. London/New York: Routledge. DOI: 10.4324/9781315753041.ch39.

[28] Hryniewicz, J. T. (2015). Polska na tle historycznych podziałów przestrzeni europejskiej oraz współczesnych przemian gospodarczych, społecznych i politycznych. Warszawa: Wydawnictwo Naukowe Scholar.

[29] Kłodziński, M. (1999). Aktywizacja gospodarcza obszarów wiejskich. Problemy Integracji Rolnictwa 3, 29-35.

[30] Kobylińska, U. (2010). Inicjatywy lokalne na rzecz poprawy jakości życia na obszarach wiejskich Podlasia-formy wsparcia. Zarządzanie Publiczne 4(12), 43-58.

[31] Kovach, I. (1997). Jakość życia na wsi w 6 wybranych krajach postsocjalistycznych. Wieś I Rolnictwo 3.

[32] Kusterka-Jefmańska, M. (2010). Wysoka jakość życia, jako cel nadrzędny lokalnych strategii zrównoważonego rozwoju. Zarządzanie publiczne 12(4), 115-122.

[33] Marks, M. (2006). Promocja a rozwój lokalny gmin wiejskich województwa łódzkiego. Wydawnictwo Uniwersytetu Łódzkiego.

[34] Michalska-Żyła, A. (2014). The quality of life and social capital in post-industrial peripheral cities. Przegląd Socjologiczny 53(1), 109-136.

[35] Murawska, A. (2012). Zmiany w poziomie i jakości życia ludności na obszarach wiejskich w Polsce. Journal of Agribusiness and Rural Development 25(3), 169-180.

[36] Nurzyńska, I. (2016). Polish rural areas and agriculture as beneficiaries of the European Union Funds. In: Wilkin, J. \& Nurzyńska, I., eds., Rural Poland 2016. Rural Development Report (pp. 88-106), Warszawa: Foundation for the Development of Polish Agriculture, Scholar.

[37] Olejniczak, J. (2012). The Development Level of Rural Municipalities in Lower Silesian Voivodeship in View of Their Income Structure. In: Klímová, V. \& Žítek, V., eds., $15^{\text {th }}$ International Colloquium on Regional Sciences Conference proceedings (pp. 100-111). Brno: Masaryk University.

[38] Pięcek, B. (2001). Rozwój infrastruktury na wsi a warunki życia ludności wiejskiej. Wieś I Rolnictwo (1), 128-138.

[39] Podedworna, H. (2010). Marketization of rural resources in Poland. Przegląd Socjologiczny $59(2), 127-145$. 
[40] Raphael, D., Steinmetz, B. \& Renwick, R. (1998). People, Places, and Priorities of Riverdale: Finding from the Community Quality of Life Project [unpublished document]. Toronto: Centre for Health Promotion.

[41] Rapley, M. (2003). Quality of life research: A critical introduction. London: Sage Publications.

[42] Rokicka, E. (2014). The concept of 'Quality of Life'in the context of economic performance and social progress In: Eißel, D., Rokicka, E. \& Leaman, J., eds., Welfare State at Risk (pp. 11-34). Springer International Publishing. DOI: 10.1007/978-3-319-01481-4.

[43] Rosner, A. ed. (2002). Wiejskie obszary kumulacji barier rozwojowych. Warszawa: IRWiR PAN.

[44] Rosner, A. (2010). Przestrzenne zróżnicowanie poziomu rozwoju społeczno-gospodarczego obszarów wiejskich a dynamika przemian. In: Stanny, M., ed., Przestrzenne, społecznoekonomiczne zróżnicowanie obszarów wiejskich a dynamika przemian (pp. 11-27). Warszawa: IRWiR PAN.owych.

[45] Schotter, A. (1981). The Economic Theory of Social Institutions. New York: Cambridge University Press.

[46] Shucksmith, M., Cameron, S., Merridew, T. \& Pichler, F. (2009). Urban-rural differences in quality of life across the European Union. Regional Studies, 43(10), 1275-1289. DOI: $10.1080 / 00343400802378750$.

[47] Spellerberg, A., Huschka, D. \& Habich, R. (2007). Quality of life in rural areas: processes of divergence and convergence. Social Indicators Research 83(2), 283-307. DOI: $10.1007 / \mathrm{s} 11205-006-9057-3$.

[48] Stanny, M., Rosner, A. \& Kozdroń, E. (2016). Changes in the Spatial Distribution of the Level and Dynamics of Socio-Economic Development of Rural Areas in Poland. Wieś i Rolnictwo 173(4), 29-47.

[49] Starosta, P. \& Michalska-Żyła, A. (2016). Jakość życia mieszkańców miast poprzemysłowych. In: Starosta, P., ed., Społeczny potencjał odrodzenia miast postprzemysłowych (pp. 65-90). Łódź: Wydawnictwo Uniwersytetu Łódzkiego.

[50] Stedman, R. C., Parkins, J. R. \& Beckley, T. M. (2004). Resource dependence and community well-being in rural Canada. Rural Sociology 69(2), 213-234. DOI: 10.1526/003601104323087589.

[51] Stiglitz, J. E., Sen, A. \& Fitouss, J. P. (2009). Report by the Commission on the Measurement of Economic Performance and Social Progress, http://www.stiglitz-sen-fitoussi.fr/documents/ rapport_anglais.pdf.

[52] Swianiewicz, P. (2013). Poland. In: Loughlinb, J., Kincaid, J., Swenden, W., eds., Routledge Handbook of Regionalism and Federalism (pp. 331-340). Abingdon: Routledge.

[53] Szymczak, M. (2005). Miasto i wieś w Polsce: dystanse w zakresie mieszkaniowych i materialnych warunków życia 1975-1997: studium z socjologii empirycznej. Wydawnictwo Uniwersytetu Łódzkiego.

[54] Wierzbicka, A. \& Żółtaszek, A. (2015). Analiza bezpieczeństwa publicznego w krajach europejskich. Wiadomości Statystyczne 8, 66-80.

[55] Wilkin, J. \& Nurzyńska, I., eds. (2016). Rural Poland 2016. The rapport of the state of Rural areas. Warszawa: Foundation for the Development of Polish Agriculture, Scholar.

[56] Wilkin, J. (2016). Polish rural areas vs. the country and Europe - synthesis of the Report. In: Wilkin, J. \& Nurzyńska, I., eds., Rural Poland 2016. Rural Development Report (pp. 916), Warszawa: Foundation for the Development of Polish Agriculture, Scholar.

[57] Woźniak, Z. (2015). Cykliczne badania jakości życia narzędziem wsparcia miejskiej strategii rozwoju. Ruch Prawniczy, Ekonomiczny i Socjologiczny 77(1), 79-99. 
[58] Yoder, J. A. (2003). Decentralisation and regionalisation after communism: administrative and territorial reform in Poland and the Czech Republic. Europe-Asia Studies, 55(2), 263286. DOI: $10.1080 / 0966813032000055877$.

[59] Zawisza, S. (1997). Potrzeby rodzin wiejskich i gospodarstw domowych na wsi w okresie transformacji rynkowej. Wieś i Rolnictwo 1.

[60] Zegar, J. St. \& Chmielewska, B. (2016). Rural population incomes: Sources, diversification and range of poverty. In: Wilkin, J. \& Nurzyńska, I., eds., Rural Poland 2016. Rural Development Report (pp. 107-125). Warszawa: Foundation for the Development of Polish Agriculture, Scholar.

\section{Other sources}

[61] Central Statistical Office (CBOS), (2013). Wieś polska - postawy i styl życia, komunikat BS/117/2013.

[62] Central Statistical Office (CBOS), (2015). Kto marzy o życiu na wsi a kto marzy o życiu w mieście? komunikat 8/2015.

[63] Fredriksson, C. (1998). Rozwój regionalny w świecie globalnej konkurencji - potrzeby nowej strategii. In: Wawrzyniak, B., ed., Zarządzanie regionem. Strategie rozwoju regionalnego w kontekście integracji Polski z Unią Europejską. 